\title{
Account of Sepulchral Deposit, with Cinerary Urns, Found at Porth Dafarch, in Holyhead Island
}

\section{The Hon. William Owen Stanley \& A. W.}

To cite this article: The Hon. William Owen Stanley \& A. W. (1849) Account of Sepulchral Deposit, with Cinerary Urns, Found at Porth Dafarch, in Holyhead Island, Archaeological Journal, 6:1, 226-239, DOI: 10.1080/00665983.1849.10850734

To link to this article: http://dx.doi.org/10.1080/00665983.1849.10850734

曲 Published online: 10 Jul 2014.

Submit your article to this journal $₫$

Q View related articles ¿ 


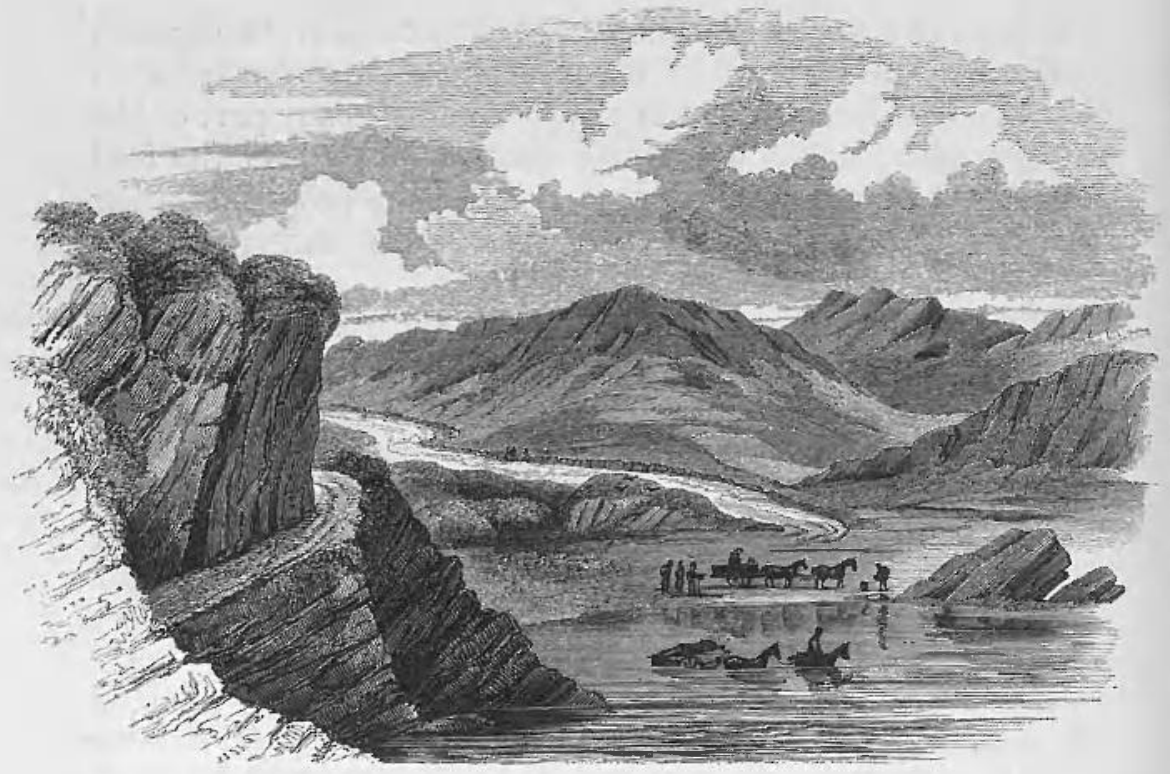

Porth Dafarch, Holyhead Island, v" The place where the Urns were found. v Tile Grave.

\section{ACCOUNT OF SEPULCHRAL DEPOSIT, WITH CINERARY URNS, FOUND} AT PORTH DAFARCH; IN HOLYHEAD ISLAND.1

COMMUNICATED BY THE HON. WLLLAM OWEN STANLEY.

WITH NOTICES OF ANCIENT INTERIENTS DISCOVERED IN ANGLESEA AND NORTH WALES.

IT is remarkable that few particulars have been recorded with precision, by antiquarian writers, regarding interments of the earlier ages discovered in North Wales. The general practice of burial under the heap of stones or mound of earth, the cairn or the barrow, appears, indeed, to have prevailed. The nature of the rude sepulchral structure must obviously, in every age, have been slightly modified in accordance with the character of the surface, or the soil : wherever this was freely strewed with fragments of stone, the carnedd would be formed ; ${ }^{2}$ whilst, in low positions, the

1 These interesting urns and remains, of especial value for comparison with discoveries in Wiltshire and other parts of England, were exhibited in the museum formed during the late Meeting of the Institute at Salisbury.

2 See accounts of sepulchral carnedds, in Anglesea, in which interments were found. Rowlands' Mona, p. 215 ; Pennant's Wales, vol. ii., pp. 259-262; Archaeo. Camb., vol. ii., p. 3. Sir R. C. Hoare adverts to the frequent occurrence of cairns or carnedds in Wales, especially on the summits of hills : they have frequently proved to be sepulchral, but, as he remarks, were occasionally raised for other purposes. Ancient Wilts, vol, ii., p. 113. Some interesting notices of sepulchral antiquities and usages in Wales, may be found in the Cambrian Register, 1796 , p. 382. See also Fenton's Pembrokeshire, pp. 237, 319, 476, 579, \&c. 
alluvial mould afforded materials for the tumulus, quickly coated and protected by the sward. In some instances the ready supply of slabs, or large pieces of rock, caused the construction of the sepulchral cist; and examples are not wanting in North Wales of receptacles of this description, in which the unburned remains have been found deposited. Such was the remarkable tomb, called Bedd Gwrthetryn, near Nevin, in Caernarvonshire, traditionally believed to have been the resting-place of Vortigern. ${ }^{3}$

There is, at present, no sufficient evidence on record to enable the archaeologist to assign vestiges of this class to distinct periods, or to classify these sepulchres in accordance with any peculiarity of their construction, or their contents. The occurrence of cinerary urns does not appear to have been frequently noticed. The careful examination of the numerous grassy tumuli in the northern extremity of Flintshire, between Newmarket and Caerwys, supposed, with much probability, to have been the scene of the slaughter of the Ordovices by Agricola, might be productive of much curious information; being examples of which the age may be considered ascertained. In these barrows, according to Pennant, urns have repeatedly been found. ${ }^{4}$ Many, doubtless, are the ancient battle-fields in the Principality, marked by the thickly ranged mounds of this description, such as are seen in the plain between Dolgelly and Tanybwlch, in Merionethshire, which would throw an important light on the obscure history and usages of our forefathers.

In the month of October, 1848, an interment, which presented some unusual circumstance in the mode of deposit, was found on the shores of the harbour, or bay, called Porth Dafarch, about midway between the South Stack and Porthy-Capel, on the estates of Lord Stanley of Alderley, in Holyhead Island. ${ }^{5}$ The tenant, Mr. Roberts, was occupied in collecting stones, suitable for the construction of some farm building. On the right of the road leading down to the bay, there was a small mound, or barrow, originally, it is probable, of greater elevation than at present : its dimensions

3 See Bishop Kennett's "Parochial Antiq. Hist. of Alchester," vol. i.g p. 437 ; Pennant's Wales, vol. i., p. 205. A remarkable group of kistvaens, surrounding a cromlech, existed near the road leading from Newport to Fishguard. They were opened by the late Sir R. C. Iloare and Mir. Fenton, and contrined charcoal,bones, fragments of rude urns and sea pebbles. Fenton's Pembrokeshire, p. 555 ; Hoare's Ancient Wilts, vol. ii., p. II5.

4 Pennant's Wales, vol. i., p. 3.

5 A brief mention of this discovery was made in the Archneologia Cambrensis, vol. iv., p. 67 . 
are about 30 feet only in circumference. It had apparently been much lowered at some period, and a rude enclosurewall had once been formed adjoining to it, or partly traversing it, by which the shape of the little tumulus had been changed. At this spot the tenant was removing a stone of some size, which seemed suitable for his purpose, and on this being displaced, an earthen urn, described as resembling a beehive, was discovered beneath, which mostly crumbled to pieces. A few fragments only were preserved,

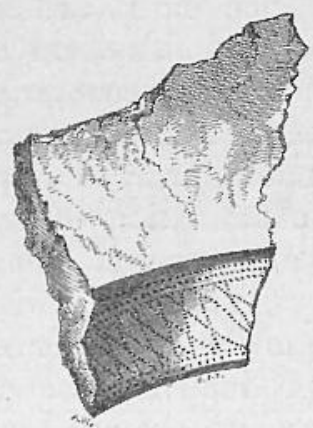
of which the most considerable is here represented. (See woodcut.) It is of a very coarse, light brown ware, formed by the hand without the lathe; the interior, near the mouth, as well as the exterior, ornamented with zigzag scorings. In general character, it appears not dissimilar to cinerary urns found in Wiltshire and other parts of England. It is probable that this large urn, which had been placed in an inverted position, had become decayed by moisture and proximity to the surface, the interment being less than 2 feet beneath the sward. It has been supposed that the urn was open, or originally broken, at the side uppermost in its actual position ; and that the opening had been closed by the flat stone, which first led to the discovery. It may seem more probable, however, that the urn had been placed entire, with the mouth downwards ; the bottom, thus inverted, being protected by a flat stone, laid over it when the mound was raised. This part, placed nearest to the surface, had become decayed, and crumbled away through the moisture and superincumbent weight.

On searching further, a small urn of unusual form and fabricated with considerable skill, was found, placed within the larger urn. Both contained ashes, fragments of burned bones and sand, of which some part had probably fallen into the cavity when the top stone was removed. The smaller urn was placed in the centre, upon a flat stone, and the exterior urn had been carefully protected all around by a little wall of pieces of shingle, set edgeways, about 6 or 8 inches in height, and serving to protect the deposit from the weight of the surrounding soil. The mouth of the urn, indeed, was so firmly fixed and embedded in this manner, 
that it proved impracticable to extricate it without breaking the vessel in pieces. This exterior urn appears to have been of great size : the diameter at the mouth must have measured nearly 13 inches; the height cannot now be ascertained. The strongest parts of the fragments, which have been preserved, measure nearly seven-eighths of an inch in thickness : the surface is of a dingy brown colour, extending only through a slight crust, the interior being dark, black, and deficient in compactness. The outer side is scored around the rim with diagonal and vertical lines, formed as if by the pressure of a coarse cord upon the clay; and it is orwamented by several grooves or channels of equal width, marked with zigzag lines, impressed in like manner, and with great regularity. Each of these last impressions seems to have been produced by a little dentated punch, about half an inch in length. On the inner side, ${ }^{6}$ the mouth of the urn is likewise ornamented with a corded pattern, about $2 \frac{3}{4}$ inches deep. (See woodcut.) The small urn, which is of lighter colour, very compact and well formed, measures $4 \frac{5}{8}$ inches diameter at mouth : its height is 3 inches; diameter of base, $1 \frac{3}{4}$ inches.

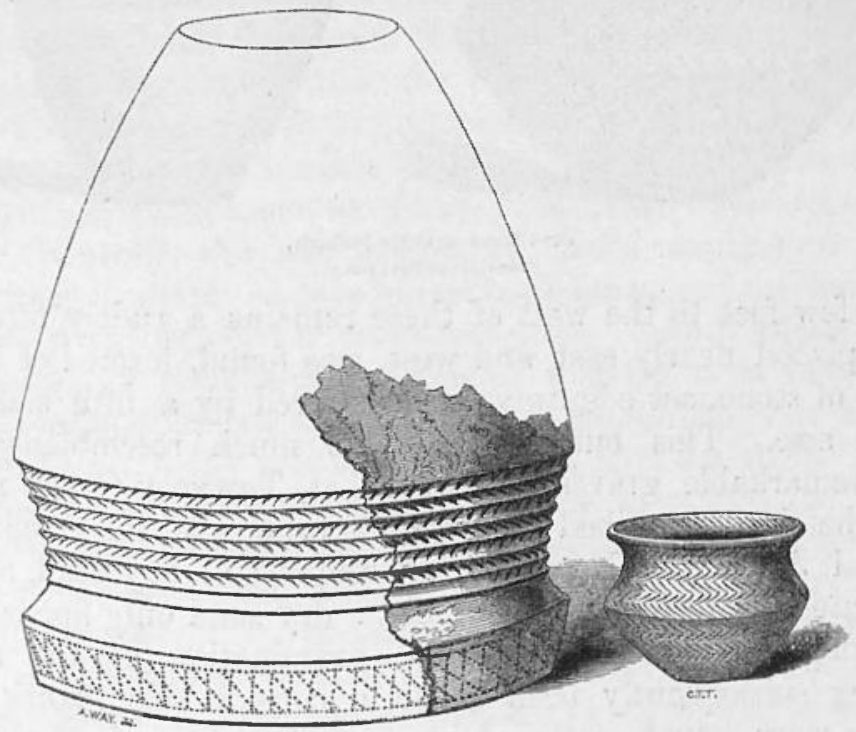

Restoration of the broken Urn, showing the supposed proportions of the pair. (One-sixth original size.)

6 This scoring on the innev' side does not appear to be of frequent occurrence. See a drinking cup, Hoare's Anc. Wilts, vol. i., p. 237 ; Fenton's Pemb., pl. 1., fig. 1, p. 350. VOI. VI. 
It is marked, over the entire surface, as is also the lip, within, by lines scored with a fine-pointed tool, and forming a succession of zigzag bands. (See woodcut.) This urn, as it is stated, was not inverted. The urns had been placed on a flat stone, forming a sort of floor. In the preceding woodcut, their proportion is shown, as nearly as it can be ascertained, by careful observation of the fragment of the larger urn.

A second similar deposit was brought to light, adjacent to that which has been described: the outer urn had become quite decayed, and crumbled into black dust; within it had been placed a small urn, of still more diminutive size than the former, and quite plain, without any ornamental scorings : it was, fortunately, preserved, and measures in height $2 \frac{5}{8}$ inches; diameter of mouth, $2 \frac{1}{2}$ inches; diameter of widest part, $3 \frac{1}{2}$ inches; base, $1 \frac{5}{8}$ inches. Like the first, it contained ashes. ${ }^{7}$ (See woodcut.)
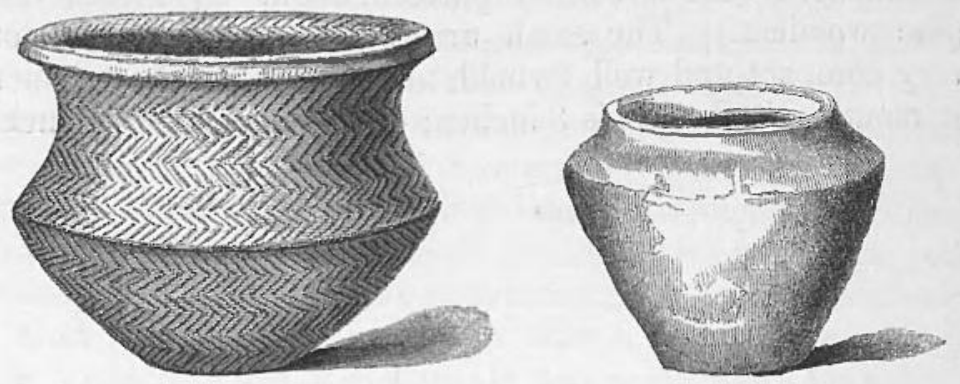

Uins found at Porth Dafarch.

(One-tbird original size.)

A few feet to the west of these remains, a rudely formed cist, placed nearly east and west, was found, formed of four slabs of stone, set edgeways, and covered by a fifth slab of large size. This burial-place bears much resemblance to the remarkable graves discovered at Towyn-y-Capel, near Holyhead, as described in a former volume of the Archaeological Journal. ${ }^{8}$ No bones, or remains of any kind, as it is stated, were found in this cist : dry sand only appeared, covering the bottom. Careful examination of the spot having subsequently been made, a considerable quantity of bones were found scattered around; but as, unfortunately, no one witnessed the first discovery, except the agricultural labourers, and the mound was afterwards disturbed by

i Compare a drinking cup (?) found in Wiltshire, very similar in form. Hoare's Ancient Wilts, vol. i., p. 85.
8 See the memoir by Hon. William 0 . Stanley, Archaeol. Journal, vol, iii., p. 226. 
persons in quest of treasure, on the report of the discovery being spread, it may be doubtful whether these dispersed remains should be assigned to the first or second place of interment above described.

Many stones of considerable size, measuring as much as 3 feet square, it should be observed, lay in the sand around : they had, possibly, formed a cairn, or a rude kistvaen, which had become denuded of soil, so that the stone covering the urn was nearly exposed. There was also a larger slab, which might have formed an upright stone, or maentivs. The mound was covered with green sward, previously to the excavation. In former ages, the sea had, probably, reached only to within 100 yards or upwards of this tumulus; but there had been a gradual encroachment, and the waves now wash the foot of the mound.

The Bay of Porth Dafarch, situated on the southern shore of Holyhead Island, about two miles S.E. of the South Stack, affords the best landing-place on that part of the coast. Shortly before the establishment of steamers-facilities being desirable for landing passengers and mails, when the packets from Dublin were occasionally wind-bound during easterly gales, and unable to round the South Stack-this bay was considered the most eligible position for the object required. Considerable expense was consequently incurred by Government in forming a road leading from Porth Dafarch to Holyhead, a distance of about two miles. The following year, however, the advantages of steam navigation were rendered available on this important station, and the landingplace, with the road of communication, became useless. A trap-dike, of considerable geological interest, runs across the bay, and may be traced near the coast, cropping out of the sand, which, being mixed with a detritus of sea-shells, forms a valuable manure, and is carted away in quantities. The general appearance of the spot, and position of tumulus, are seen in the view which accompanies this memoir. (See p. 226.)

It is much to be regretted that no precise statement of this discovery can now be obtained; the particulars above given have been collected by careful inquiries from the tenant. In the neighbourhood of the spot, further inland, there are several green mounds, which have some appearance of being sepulchral, but the sand has drifted much, and formed round heaps over projections of the rock.

The supposition which the appearance of the two urns (first 
described) suggested, was, that the tumulus might have covered the remains of a mother and her infant, and this conjecture has been strikingly confirmed by subsequent investigation. On submitting the remains with which the small urn was filled to the examination of an eminent comparative anatomist, Mr. John Quekett, Assistant Curator of the Museum of the College of Surgeons, to whose obliging aid in elucidating questions connected with animal remains the Institute had previously been indebted, that gentleman at once pointed out half-burnt fragments, which might undeniably be distinguished as portions of the skeleton of a very young infant, with other fragments, the remains of a young adult, the age presumed, from the occurrence of a fragment of the jaw-bone, enclosing one of the "wisdom teeth" not yet cut, to have been about twenty-four years. The bone of a frog was also found, with several small land shells; and, on close inspection of the sand, six or seven living specimens of the Ptinus fur appeared, some perfect insects, others in the pupa or larva state. These little beetles were unusually small and pale-coloured, arising, doubtless, from long confinement in so unusual a position, the Ptinus commonly feeding on wood, paper, or leather. A doubt has been expressed, whether it were possible that animal life could be thus preserved; and it was suggested that the insects might have found their way into the urn after its discovery. This, however, certainly had not occurred. The larger fragments of bone were all found to be channelled by the slow operations of these little creatures, whose food, in their larva state, these half-burnt remains had supplied. On submitting the insects and portions of bone to Mr. Westwood, one of our highest authorities in all that concerns insect life, he at once named the species, pointed out its diminutive growth, owing to unsuitable food and being kept from the air ; and he recognised the slow operation of the larva in the furrowed bones, which served to sustain life. Mr. Westwood also stated that similar examples of the preservation of insects had come under his observation, and adverted especially to a remarkable instance noticed a few years since in Lancashire. ${ }^{1}$

Among the sand and bones, one small rivet, as it seemed, of bronze, in perfect preservation, was found; it measured

9 See the curious evidence lindly supplied by that gentleman in regard to the tradition of human skin, at Hadstock, \& c.,
Archaeol. Journ., vol.ii., p. 185.

1 An account of this curious discovery will be given hereafter. 
about an eighth of an inch only in length, but sufficed to prove that some object, of wood, bone, or other perishable material, and compacted with metal, had been either burned or deposited with the remains. On emptying the little urn, a remarkable appearance was noticed: numerous filaments, evidently the remains of some vegetable structure, formed a kind of irregular network over the interior surface of the urn. At first sight, a supposition suggested itself that these might be the traces of a mycoderma, or some vegetation, which had become developed in the urn subsequently to the deposit, and in consequence of moisture. On careful examination, however, with a powerful lens, Mr. Quekett was enabled to affirm that these were the dry ribs of the leaf of some species of Pteris, a kind of fern abounding near the spot. He compared the structure with recent specimens of fern, and the fact seemed undoubted that the urn had been lined with leaves of that plant previously to the ashes being placed in it. With these leaves, possibly, might have been introduced the germ of insect life, the singular development of which has been described.

A circumstance deserving of attention also presented itself in the examination of these remains. With the portions of human bone appeared fragments, which could confidently be pointed out as those of some small animal. Mr. Quekett was unable positively to assert the kind of creature to which they had belonged, but he stated his opinion that they probably formed part of a small dog.

It must be noticed, that only a small portion of the contents of the two urns were procured and submitted to scientific examination. It is very probable that some of the remains originally placed in the larger urn had, in the confusion of opening the mound, without any proper care, been mixed with those of the smaller vase. This cannot now be ascertained, nor whether the remains were originally placed in distinct receptacles respectively, but the facts now detailed are the result of the most careful investigation, and it appears certain that the deposit consisted of the remains of a person in the prime of life, probably a female, and of an infant newly born, or of the tenderest age.

The existence of the remains of a dog in this deposit, although it cannot be affirmed positively, is by no means improbable. It is stated that the bones of dogs have repeatedly been discovered in the tumuli opened in Wiltshire; it may suffice to advert to an instance which occurred during 
the : researches of the late Sir Richard Colt Hoare, near Everley, in that county. ${ }^{2}$ In this barrow the skeleton of the dog was not, indeed, laid with the burnt remains of his master; it lay above them, much nearer the surface, but there can be little question that, as Sir Richard remarked, the deceased, whose bones were found surrounded by a wreath of the horns of the red deer, with several arrow-heads of flint among the ashes, had been skilled in the chase, and that his faithful attendant had been interred over his grave. The bones of the horse have also repeatedly been found in British tumuli. ${ }^{3} \quad$ These usages in our country are strikingly in accordance with the ancient practice of the Gauls, recorded by Cæsar, who states that the funerals of that people were not devoid of sumptuous ceremony, and that they threw upon the pile every object, and even those animals which the deceased, when living, had regarded with attachment. "Funera sunt, pro cultu Gallorum, magnifica, et sumptuosa; omniaque, quæ vivis cordi fuisse arbitrantur, in ignem inferunt, etiam animalia." 4 The deposit of an urn of diminutive size, enclosed within one of large dimensions, is a circumstance specially deserving of notice, as of exceedingly rare occurrence in the investigation of British interments.

The usual character of such deposits in Wales is thus given by Pennant, in his account of Llanarmon, Flintshire. "Sepulchral tumuli" (he observes) "are very frequent in this parish. I was present at the opening of one, composed of loose stones and earth, covered with a layer of soil about 2 feet thick, and over that a coat of verdant turf. In the course of our search were discovered, towards the middle of the tumulus, several urns made of sun-burnt clay, of a reddish colour on the outside, black within, being stained with the ashes they contained. Each was placed with the mouth downwards on a flat stone; above each was another, to preserve them from being broken by the weight above. Mixed with the loose stones were numerous fragments of bones, such as parts of the thigh bones, the arm bones, and even a skull. These had escaped the effects of the fire of the funeral pile, and were deposited about the urns, which contained the residuum of the corpse that had been reduced to pure ashes." 5

2 Ancient Wilts, vol. i., p. 184 . See the account of barrows opened near Amesbury, pp. 124, 125; and at Wilsford, pp. 208, 216. The slieletons of the dogs were usually found above, as if interred posterior to the primary deposit.

3 Ancient Wilts, vol. i, p. 86.

4 Caes. Comment., lib. vi., c. 19.

3 Tour in Wales, vol. i., p. 381. 
In tombs of the Anglo-Roman age, the remarkable usage of enclosing a small cinerary urn in one of larger size, has repeatedly been found; for instance, at Lincoln, and in the cemetery at Deveril Street, Southwark, where two large ossuaria, enclosing urns, were found in 1836. (Archaeologia, vols. xii., p. 108 ; xxvi., p. 470 ; and xxvii., p. 412). Mr. Disney has preserved, in his valuable Museum of Antiquities, at the Hyde, Essex, a diminutive vase, found within one of large size, at West Hanningfield Common, in 1823. Both contained bones, those which filled the smaller vase being of very small size, and the supposition naturally suggested itself, that the urns contained the remains of a mother and her infant. $^{6} \quad$ A fine globular ossuarium, with a cinerary vase enclosed in it, found during recent railway operations at old Ford, Essex, is in the possession of the Dean of Westminster. In recent discoveries at Balmer, near Lewes, a number of Anglo-Roman cinerary urns have been found, each enclosing a small urn, inverted, and apparently not containing ashes. In tumuli of the earlier period, small vessels, of various forms, designated by Sir Richard C. Hoare as drinking cups, have often been found, placed near the remains, at the feet of the skeleton, or at the side of the head, but in no case, as far as I am aware, within any British cinerary urn found in Wiltshire. Sir Richard Hoare notices repeatedly the burial of infants in Wiltshire barrows, and occasionally with remains, probably of the mother, as at Cop Head Hill, near Warminster. ${ }^{7}$ In a tumulus near Amesbury he discovered two skeletons of infants deposited in a very singular manner, each having been placed over the head of a cow, which, we might conjecture, had supplied nourishment during the brief term of life. It must be noticed, as a curious observation, that in every case thus described, the skeleton has been found, indicating, as it might be thought, a peculiar usage, as regards children of tender age, analogous to that of the Romans; among whom, as shown in the Memoir on Mr. Neville's curious researches at Chesterford, given in this Journal, the burial of infants was not accompanied by cremation. $^{8}$

\footnotetext{
"See the "Museum Disneianum." A representation of the small urn has been previously given in the Archieol. Journal, P. 85, of this volume.

' Ancient Wilts, vol. i., p.68. A sea

shell (Nerite) lay near the infant skeleton. See also interments of infants, PD. 77, $115,118,121,159,167$, and 211 .

A Archaeol. Journal, p. 2l, of this volume.
} 
The question naturally occurs, whether the tumulus at Porth Dafarch ought to be regarded with certainty as a British burial-place; or whether, situated so close to the shores which, from the earliest times, must have been exposed to piratical incursions of Danes and Northmen, and especially to the assaults of the restless plunderers from the opposite coasts of Ireland, the vestiges of olden times now described may not be assigned to the stranger, to whose aggressions these parts were, even as late as the thirteenth century, frequently a prey. The inquiry is one of considerable interest. It is very probable that the Irish made occasional sojourn on these coasts : Camden, indeed, asserts distinctly that, upon the decline of the Romans, invaders from Ireland came into Anglesea, and cites in proof, the existence of certain hillocks, surrounded by a foss, which are called "the Irishmen's huts," as also the spot named from that people, "Yn hericy G widil," the scene of their victory, under Sirigi, over the aborigines. ${ }^{9}$ The annotators on Camden have questioned the correctness of the words "Yn hericy Gwidil," and suppose them to have been printed erroneously for Cerig-y-Gwydel, "Irish stones;" for a place so called is found in Llan Gristiolis parish, adjacent to Din Drivel, a fortress near which Caswallon routed the Irish. In a wood at Llygwy, on the north-east coast of Anglesea, there were to be seen certain walls, rudely constructed of large stones in circular order, enclosing spaces about fifteen feet in diameter; these were commonly called "Cittier Gwydhelod," or Irish cots. Rowlands, in his Mona, describes these sites of primitive dwellings upon the open heaths, and Rhosydh, or habitable lands, of Anglesea, consisting of oval or circular trenches, universally admitted to have been occupied by small dwellings, and called "Cyttie'r Gwyddelod, viz., the Irish men's cottages." He questions, however, their having been occupied by. Irish, who came only for pillage, and had no occasion to construct cottages; whilst the term Gwyddelod,-sylvestres homines, - as he asserts, denoted the aborigines, - the wood-rangers, by whom the island was first cleared.' Sir William Betham appears to concur in this notion. On the west flank of Holyhead mountain, at the farm belonging to Lord Stanley, Ty Mawr, as also on the north-east side, near the quarries lately opened, there exist mounds of the kind in question, which have always been called the "Irishmen's huts, - Cyttir Gweddilod." They are situated above a creek on the coast, not far from the South Stack, favourable for the landing of pirates from Ireland; and in these mounds were discovered, about the year 1834, various objects of bronze, spear-heads, celts, rings, \&c., resembling such as are frequently found in that island. ${ }^{2}$ The little inlet is still known by the name Porth-y-Gwyddel. The probability that this spot, at no great distance from Porth Dafarch, might have been occupied by the pirates, appears to favour the popular tradition; whilst the ancient designation of the spot where Sirigi made slaughter of the natives, near Aberfraw,-Cerrig

0 "Hoc tamen attexam: Romanorum in Britannia jam divergente imperio, quidam ex Hibernia iu hanc (Auglesey) etiam irrepserunt. Nam præter tumulos fossa circundatos, quos Hibernicorum casulas vocant, etiam locus est $Y_{n}$ hericy Gwidil ab Hibernicis denominatus, qui duce Sirigi, Britannos eo loci fuderunt, ut Triadum libro memoratur." Camden, Brit., p. 540, ed. 1607. 1766 .

2 They were exhibited to the Society of Antiquaries by Lord Stanley, May 21, 1835. Archaeologia, vol. xxvi., p. 483. 
-y-Gwyddel, -and that of the scene of his defeat by Caswallon, about A.D. 440,-Llan-y-Gwyddel, or Cappel Gwyddel,-near Holyhead Church, may justly be regarded as corroborative of the notion that the name is applicable rather to the Irish rover, than to the first settler in those islands. ${ }^{3}$ Some mention of this curious subject has previously been made in the Journal ; it may suffice now to remark that the smaller urn found at Porth Dafarch, wholly covered with zig-zag scorings, is both dissimilar in form to those found in England or Wales, and in its fabrication wholly different to the larger urn, by which it was covered. This last bears a greater resemblance to primitive cinerary vases of England and Wales, whilst the few examples described as found in the sister kingdom, are far more elaborately ornamented with chevrony scored lines over the greater part of the surface, and appear analogous to the smaller urn, above described. May not this little cup have been brought from Ireland by the pirate chieftain, and the larger vessel have been the ordinary manufacture of the natives of Mona? ${ }^{4}$

It has been stated also, that, in Ireland small urns have been found, not unfrequently, deposited within those of larger size, containing bones and ashes. ${ }^{5}$ Mr. John Bell, of Dungarvan, communicated to the Archaeological Association in 1845 , a very curious account of such a deposit: the large urn was inverted on the floor of a rudely formed chamber; within it was the smaller vessel placed amongst the ashes, and, as in the interment at Porth Dafarch, in an erect position.

The deficiency of circumstantial statements respecting cinerary urns, and the details of sepulchral usages in Wales, has already been stated. It may, therefore, be desirable to append to the foregoing memoir, the brief notice of a discovery of singular interest, in Anglesea, of which, it is believed, no account has hitherto been given, except in a valuable periodical of limited circulation, the "Cambro-Briton," from which the following particulars are extracted :-

"It is said, in the Additions to Camden, edited by Gough (vol. iii., p. 200) that, according to tradition, the largest of the numerous cromlechs in Anglesea is the monument of Bronwen, daughter of Llyr Llediaith, and aunt of Caractacus. The precise site of this noted pile is not stated : a local antiquary of the last century, Mr. Griffith, in a letter to $\mathrm{Mr}$. Vaughan of Hengwrt, speaking of Anglesea as the burial-place of many distinguished persons in ancient days, observes, 'as to Brownwen, the daughter of Leir, there is a crooked little cell of stone, not far west of Alaw, where, according to tradition, she was buried."

In 1813 an interment was found on the banks of the river Alaw, in Anglesea, of which the following account was communicated to the "Cambro-Briton," by the late Sir Richard Colt Hoare, having been sent to him by Richard Fenton, Esq., of Fishguard. ${ }^{6}$ Its special interest was thus stated by Sir Richard:-

"During the long and minute examination of our numerous barrows in

${ }^{3}$ Rowlands' Mona, pp. 27, 37, 147 ; Pennant's Wales, vol, i., p. 277.

${ }_{4}$ Compare the elaborately decorated urns found in the Co. Down, Dublin Penny Journal, vol. i., p. 108 ; and in Co. Tyrone, VOL. VI.
Journal of Brit. Archaeol. Assoc., vol. i., p. 244.

5 Journal Archaeol. Assoc., ibid.

- Cambro-Briton, vol, ii., p. 71 . October, 1820 .

$\mathrm{K} \mathrm{K}$ 
Wiltshire, and especially in the neighbourhood of Stonehenge, I had often reason to lament, that, by their contents, we could form no conjecture, either at what period, or to what personage, the sepulchral tumulus was raised. But, from the following record, this mysterious deposit seems to have been ascertained:

"A farmer, living on the banks of the Alaw, a river in the Isle of Anglesea, having occasion for stones, to make some addition to his farm. buildings, and having observed a stone or two peeping through the turf of a circular elevation on a flat not far from the river, was induced to examine it, where, after paring off the turf, he came to a considerable heap of stones, or carnedd, covered with earth, which he removed with some degree of caution, and got to a cist formed of coarse flags canted and covered over. On removing the lid, he found it contained an urn placed with its mouth downwards, full of ashes and half-calcined fragments of bone. The report of this discovery soon went abroad, and came to the ears of the parson of the parish, and another neighbouring clergyman, both fond of, and conversant in, Welsh antiquities, who were immediately reminded of a passage in one of the early Welsh romances, called the 'Mabinogion' or 'Juvenile Tales,' the same that is quoted in Mr. Davis's 'Latin and Welsh Dictionary,' as well as in Richards', under the word Petrual, (square)-

'Bedd petrual a wnaed i Fronwen ferch

Lyr ar lan Alaw, ac yno y claddwyd hi.'

- A square grave was made for Bronwen, the daughter of Llyr, on the banks of the Alaw, and there she was buried.'

"Happening to be in Anglesea soon after this discovery, I could not resist the temptation of paying a

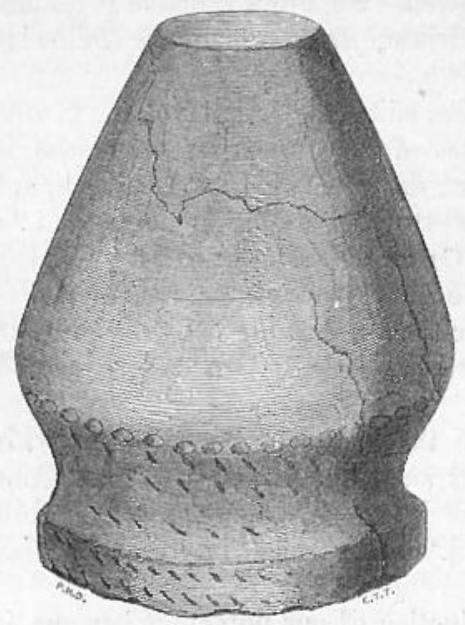

Urn of Bronwen the Fair. Date, circa A.D. 50. (One-sixth original size.) than little pricked dots, in height from about a foot to fourteen inches, and nearly of the following visit to so memorable a spot. I found it, in all local respects, exactly as described to me by the clergyman above mentioned, and as characterised by the passage cited from the romance. The tumulus raised over the venerable deposit was of considerable circuit, elegantly rounded, but low, about a dozen paces from the river Alaw. [This spot is still called Ynys Bronwen, or the Islet of Bronwen, which is a remarkable confirmation of the genuineness of this discovery.—Ed. Camb.-B.] The urn was presented entire, with the exception of a small bit out of its lip, was ill-baked, very rude and simple, having no other ornament

.7 Sir Richard has given an extract of this curious account. Ancient Wilts, vol. ii., p. 112. 
shape. $^{.}$When I saw the urn, the ashes and half-calcined bones were in it. The lady, to whom the ancient tale ascribes them, was Bronwen, daughter of Llyr Llediaith, (of foreign speech), and sister to Bran the Blessed, as he is styled in the Triads, the father of Caractacus. By the Romance her adventures are connected with Ireland, where she was ill-treated by Matholwch, then ling of that country, in consequence of which she left it, and landing in Wales, the Romance tells us, she looked back upon Ireland, which freshening the memory of the indignity she had met with there, broke her heart. To confirm the fact of the affront given her, one of the Triads (that very ancient and singular Welsh chronicle by Threes) records it as one of the three mischievous blows (with the palm of the hand) of Britain, viz., the blow of Matholwch the Irishman (Gwyddelian), given to Bronwen, the daughter of Llyr."

In 1821. Bronwen's urn was in the possession of Mr. R. Llwyd, of Chester.' It was subsequently deposited in the British Museum, and by the kindness of Mr. Hawkins, leeper of the antiquities, we are now enabled to give a correct representation of this interesting relic. Its dimensions are as follows. Height, 12 in.; greatest diam., 11 in.; diam. of mouth, 9 in.

In the periodical to which we are indebted for the foregoing account, a curious notice is also preserved of the discovery, in March, 1821, of ten uns at Llysdu, Caernarvonshire, near a supposed Roman way. They lay about a foot beneath the surface, occupying a circular space, about five yards in diameter, which appeared to have been surrounded by a wall. They were of rude fabrication, filled with bones, and in one was a small piece of bronze. Each urn was protected by four upright stones, forming a small cist, with a flat stone on the top. Unfortunately they quickly crumbled to dust, and no portions could be preserved. ${ }^{2}$

A. W.

\section{ON THE GAD-WHIP SERVICE, RENDERED AT CAISTOR CHURCH, FOR LANDS AT BROUGHTON, LINCOLNSHIRE.}

ANY one who has given to the pages of Blount's Ancient Tenures even a cursory attention, must have been amused, not only with the variety, but in some instances with the singularity of the rents and services reserved by our kings and their barons, on granting out lands to tenants when military service or the value of the return was not an object. Of these the services in Grand Serjeanty formed a numerous class, being for the most part those of which we were accustomed to hear when a coronation was about to take place,

8 A figure was given in the CambroBriton, supplied by Mr. John Fenton, partly from his father's sketch, "and from having seen some scores of the same urns, which are uniform in their proportions or shapes, whether found in Wales, Wiltshirc, or elsewhere."

D Sec the "Three Fatal Slaps." CambroBriton, vol. ii., p. 10.

1 Note in Cambro-Briton, vol. ii., p. 371.

2 Cambro-Briton, vol. ii., p. 430. 